\title{
Thermophysiological traits in four exotic breeds of rabbit at least temperature- humidity index in humid tropics
}

\author{
Olatunji Abubakar Jimoh ${ }^{1,2^{*}}$ and Emmanuel Olubisi Ewuola ${ }^{1}$
}

\begin{abstract}
Background: We deciphered thermoregulatory activities of exotic breeds of rabbit in the event of least thermal discomfort in Ibadan, Nigeria. This investigation was carried out between July and August during the least temperature-humidity index (THI). Twenty bucks and 14 doe per breed, housed individually and randomly assigned to experimental units in a completely randomized design, were used for assessment of respiratory rate (RR), heart rate (HR), rectal temperature (RT) and ear temperature (ET). Measurements were taken between 07.00 to $09.00 \mathrm{~h}$ and 16.00 to $18.00 \mathrm{~h}$ of the day, using standard procedures.

Result: The result obtained showed that the effect of sex was evident in respiratory and heart rates, with males having higher values in the evening. But the core body temperature was not affected. Although the higher function of thermoregulatory apparatus of Fauve de Bourgogne, Chinchilla and British Spot rabbits were recorded, New Zealand White had lower core body temperature than other breeds.

Conclusion: We reported that August was the most thermal comfortable period during the year for rabbit in Nigeria. New Zealand White has a lower core body temperature without a compensatory increase in thermoregulatory activities.
\end{abstract}

Keywords: Temperature-humidity index, Thermal comfort, Rabbit breeds, Nigeria

\section{Background}

Heat stress is one of the most critical stressors especially in hot regions of the world. Factors such as species of animal, the physiological status of the animals, the relative humidity, velocity of ambient air and the degree of solar radiation determines animals' zones of thermal comfort. The comfort zone temperature for rabbits is around 18 to $21{ }^{\circ} \mathrm{C}$ (Marai, Ayyat, \& Abd El-Monem, 2001). Means by which animal maintains its body temperature is widely referred to as thermoregulation.

At either higher or lower temperature, the animal has to expend energy to maintain its body temperature. The heat load in rabbit increases by exposure to a high environmental temperature, and animals try to sustain homeothermy by using internal physiological means to help re-establish

\footnotetext{
* Correspondence: abubakarjimoh2011@gmail.com

${ }^{1}$ Animal Physiology and Bioclimatology unit, Department of Animal Science, University of Ibadan, Oyo State, Nigeria

${ }^{2}$ Agricultural Technology Department, Federal Polytechnic Ado Ekiti, Ado Ekiti, Ekiti State, Nigeria
}

thermal balance. Rabbits use general body position, breathing rate and peripheral temperature (especially ear temperature), as three means to increase heat loss. An animal must dissipate the excessive amount of metabolic heat produced into the surrounding environment to control body temperature. This heat regulation can be achieved through different ways of heat losses such as physical, i.e. conduction, convection and radiation and/or evaporation (Collier, Dahl, \& VanBaale, 2006). The rate of exchange depends on the ability of the environment to accept heat and vapour and also on the animal production status (Maya-Soriano, 2012). When animals are exposed to changes in their environment that prevent them from expressing full genetic potential, consequently, such stressor is often blamed for suboptimal productive efficiency (Dobson, Tebble, Smith, \& Ward, 2001). Fuquay (1981) and Morrison (1983) reported that environments of high temperatures and humidity were detrimental to the productivity and reproductive process of commercial animals. Adaptation to heat stress requires the physiological 
integration of many organs and systems viz. endocrine, cardiorespiratory and immune system (Altan, Pabuccuoglu, Alton, Konyalioglu, \& Bayraktar, 2003). Due to few functional sweat glands in rabbits, thermoregulation in rabbits is rather poor (Naqvi, Gulyani, \& Singh, 1995). A significant part of Nigeria is characterised as humid tropic and usually subjected to extended periods of high ambient temperature and humidity. The primary non-evaporative means of cooling conduction, convection and radiation becomes less efficient with rising ambient temperature, and under such conditions, animal becomes increasingly reliant upon evaporative cooling in the form of sweating and panting to alleviate heat stress (Kimothi \& Ghosh, 2005; Naqvi et al., 1995). Analysis of domestic animal resource is very crucial for management decision making on conservation and for fitness-adaptability trait improvement (Ilori, Isidahomen, \& Akano, 2012). There is increase possibility of genetic selection for heat-tolerant animals due to genetic variation among animals for cooling capability. This is corroborated by Hansen (2009) that existence of allelic variation in genes controlling body temperature regulation and cellular resistance to heat shock means that genetic adaptation to increasing global temperature will be possible for many species. Paucity of information exists on thermoregulatory apparatus of rabbits under climatic conditions of West Africa. Assessment of thermoregulatory activities of exotic breeds of rabbit in Ibadan will provide basis for their adaptability and tolerance to the prevailing environmental situation in humid tropical region. Thus, this study aimed to assess the thermoregulatory activities of exotic breeds of rabbit during peak of thermal comfort obtained in Ibadan, Nigeria.

\section{Methods}

\section{Experimental site}

The research was carried out at the rabbit unit of the Teaching and Research Farm of University of Ibadan, Ibadan, Nigeria. It is situated in rainforest agro-ecological zone, Southwest of Nigeria, between lat. $7^{\circ} 27^{\prime} 18.744^{\prime \prime} \mathrm{N}$ and $7^{\circ} 27^{\prime} 19.17^{\prime \prime} \mathrm{N}$ and long. $3^{\circ} 53^{\prime} 13.98^{\prime \prime} \mathrm{E}$ and $3^{\circ} 53^{\prime}$ $32.69^{\prime \prime} \mathrm{E}$.

\section{Experimental animals, design and management}

This experiment lasted for 8 weeks, carried out within July and August, when least temperature-humidity index (THI) is observed at the experimental site as reported by Jimoh (2016). Four exotic breeds of rabbit consisting of Fauve de Bourgogne, Chinchilla, British Spot and New Zealand White were used for the investigation. It composed of 20 bucks and 14 does per breed, housed individually. Animals were confirmed to be without abnormalities, conform to the breed categorisation and of good health status.
Animals were housed individually and allotted randomly into experimental units in an entirely randomized design. The animals were fed $5 \%$ of their body weight, with diets containing crude protein $17.05 \%$, digestible energy $2592.06 \mathrm{Kcal} / \mathrm{kg}$, crude fibre $10.02 \%$, calcium $0.45 \%$ and phosphorus $0.21 \%$. We provided freshwater to the animals during the study period. Other routines and periodic management practices necessary for rabbit production were carried out.

\section{Meteorological data of the rabbitry microclimate}

Daily temperature and relative humidity of the rabbitry microclimate was recorded at $07.00 \mathrm{~h}$ every morning and $16.00 \mathrm{~h}$ evening during the study period using a thermo-hygrometer. The ambient temperature and relative humidity were used to compute the temperaturehumidity index.

\section{Thermoregulatory assessment}

Thermoregulatory indices of rabbit measured include respiratory rate $(\mathrm{RR})$, heart rate $(\mathrm{HR})$, rectal temperature (RT) and ear temperature (ET). Measurements were taken between 07.00 to $09.00 \mathrm{~h}$ and 16.00 to $18.00 \mathrm{~h}$ of the day. We measured rectal and ear temperature with a digital thermometer. The ear temperature was measured by placing the digital thermometer in direct contact with the central area of the auricle. The RR was measured by visually counting the flank movement for $1 \mathrm{~min}$. The HR was measured using a stethoscope. The temperaturehumidity index (THI), an indicator of thermal comfort level for animals in an enclosure, was calculated as modified by Marai et al. (2001).

\section{Statistical analysis}

Data obtained in this study were subjected to descriptive statistics and analysis of variance. General linear procedure of statistical analysis software was employed to detect significant effects with a confidence level of $95 \%$, and means were separated with new Duncan's multiple range test.

\section{Results}

The temperature-humidity index of the rabbit pen during the least temperature-humidity index of Ibadan is presented in Fig. 1. The month of July had higher THI than August. In the morning, the THI of July and August were 24.82 and $24.05{ }^{\circ} \mathrm{C}$, respectively, and in the afternoon, THI were 30.50 and $2605{ }^{\circ} \mathrm{C}$, respectively. The average monthly THI for July and August were 27.66 and 25.05, respectively. The range of THI values obtained for July and August in the University of Ibadan between 2009 and 2014 was $23.61-25.30{ }^{\circ} \mathrm{C}$ and $23.42-25.43^{\circ} \mathrm{C}$, respectively as reported by Jimoh (2016). The average monthly THI for July and August in the rabbitry microclimate were higher than the THI values obtained in the University of 


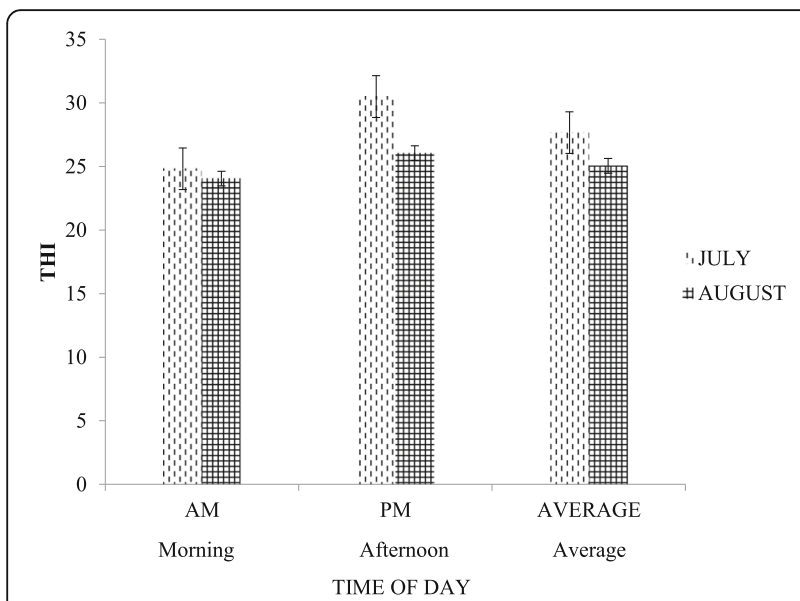

Fig. 1 Temperature-humidity index of rabbit pen during the least temperature-humidity index (LTHI)

Ibadan from 2009 to 2014 except 2013 (Jimoh, 2016). The difference could be due to the contributions of rabbit inhabitation in the pen to increase the ambient temperature and humidity and its efficient dissipation in the enclosure (rabbitry), compared to the meteorological station.

Comparison of thermoregulatory function of male and female exotic rabbits during the least temperaturehumidity index is shown in Table 1. In the morning, respiratory rate and ear temperature of both sexes were statistically similar, while the heart rate and rectal temperature of males were significantly $(p<0.05)$ higher than those of females. In the evening, the respiratory rate and heart rate of males were significantly $(p<0.05)$ higher than those of females while both sexes had statistically similar ear and rectal temperatures.

The thermoregulatory function of four exotic breeds of rabbit during the least THI is presented in Table 2. In the morning, the respiratory rate of Fauve de Bourgogne, Chinchilla and British Spot rabbits were similar $(p>$ $0.05)$, but statistically $(p<0.05)$ higher than that of New

Table 1 Effect of sex on thermoregulatory functions of exotic breeds of rabbit during LTHI

\begin{tabular}{llll}
\hline Period & Parameters & $\begin{array}{l}\text { Male } \\
N=32\end{array}$ & $\begin{array}{l}\text { Female } \\
N=36\end{array}$ \\
\hline AM & Respiratory rate beats $/$ min & $222.13 \pm 2.08$ & $218.00 \pm 1.52$ \\
& Heart rate beats $/$ min & $177.59 \pm 4.76^{\mathrm{a}}$ & $152.09 \pm 3.25^{\mathrm{b}}$ \\
& Ear temperature ${ }^{\circ} \mathrm{C}$ & $33.99 \pm 0.09$ & $33.80 \pm 0.14$ \\
& Rectal temperature ${ }^{\circ} \mathrm{C}$ & $37.60 \pm 0.08^{\mathrm{a}}$ & $37.41 \pm 0.05^{\mathrm{b}}$ \\
PM & Respiratory rate beats $/ \mathrm{min}$ & $231.22 \pm 2.09^{\mathrm{a}}$ & $220.02 \pm 1.48^{\mathrm{b}}$ \\
& Heart rate beats $/$ min & $194.91 \pm 3.44^{\mathrm{b}}$ & $152.19 \pm 14.08^{\mathrm{b}}$ \\
& Ear temperature ${ }^{\circ} \mathrm{C}$ & $36.13 \pm 1.60$ & $35.68 \pm 1.00$ \\
& Rectal temperature ${ }^{\circ} \mathrm{C}$ & $38.04 \pm 0.06$ & $37.92 \pm 0.04$ \\
\hline
\end{tabular}

$\mathrm{a}, \mathrm{b}$ Means in the same row with different superscripts are significantly $(p<0.05)$ different
Zealand White. The heart rate of Fauve de Bourgogne, British Spot and New Zealand White were significantly $(p<0.05)$ higher than that of Chinchilla rabbits.

The four breeds had statistically similar ear temperature, but the rectal temperature of the rabbits was influenced by breed.

Fauve de Bourgogne and Chinchilla rabbits had higher rectal temperature than British Spot and New Zealand White. In the evening, the respiratory rate and ear temperature across the breed followed similar trends as observed in the morning. The four breeds had statistically identical ear temperature, but the rectal temperature of the rabbits was influenced by breed. Fauve de Bourgogne and Chinchilla rabbits had higher rectal temperature than British Spot and New Zealand White. In the evening, the respiratory rate and ear temperature across the breed followed similar trends as observed in the morning. The heart rate of Chinchilla rabbits was not significantly $(p>$ $0.05)$ different from other breeds. British Spot and New Zealand White rabbits have similar heart rates but significantly $(p<0.05)$ higher than that of Fauve de Bourgogne rabbits. The rectal temperature of Fauve de Bourgogne, Chinchilla and British Spot rabbits were similar but had significantly $(p<0.05)$ higher values than that of New Zealand White.

The average daily respiratory and heart rates of four exotic breeds of rabbit at least THI in Ibadan are shown in Fig. 2. The respiratory rates of Fauve de Bourgogne, Chinchilla, British Spot and New Zealand White rabbits were $225.4 \pm 1.64,225.53 \pm 1.50,223.33 \pm 2.00$ and 212.69 \pm 1.63 beats per minute, respectively, while the observed heart rates for Fauve de Bourgogne, Chinchilla, British Spot and New Zealand White rabbits were $175.53 \pm 8.23$, $145.00 \pm 3.49,168.84 \pm 4.52$ and $163.16 \pm 3.92$ heart beat per minutes, respectively at the least THI.

The daily ear and rectal temperature of the four exotic breeds of rabbit at the least THI is presented in Fig. 3. The rectal temperatures recorded at the least THI were $37.83{ }^{\circ} \mathrm{C}$ (Fauve de Bourgogne), $37.81{ }^{\circ} \mathrm{C}$ (Chinchilla), $37.68{ }^{\circ} \mathrm{C}$ (British Spot) and $37.4{ }^{\circ} \mathrm{C}$ (New Zealand White), while ear temperatures of $34.21{ }^{\circ} \mathrm{C}$ (Fauve de Bourgogne), $34.13{ }^{\circ} \mathrm{C}$ (Chinchilla), $36.01{ }^{\circ} \mathrm{C}$ (British Spot) and $34.95{ }^{\circ} \mathrm{C}$ (New Zealand White) observed at least THI. New Zealand white had lower statistical respiratory rates than other breeds which had similar values; Chinchilla had least significant heart rates among all the breeds.

\section{Discussion}

Temperature-humidity index (THI) is an indicator of thermal comfort level for animals in enclosure. The THI values of 27.66 and 25.05 obtained in July and August respectively indicated that rabbits were not exposed to heat stress (less than 27.80) during July and August in the study period. This suggests that the month of 
Table 2 Thermoregulatory response of exotic breeds of rabbit during LTHI

\begin{tabular}{llllll}
\hline Period & Parameters & $\begin{array}{l}\text { Fauve de Bourgogne } \\
N=17\end{array}$ & $\begin{array}{l}\text { Chinchilla } \\
N=17\end{array}$ & $\begin{array}{l}\text { British spot } \\
N=17\end{array}$ & $\begin{array}{c}\text { New Zealand } \\
\text { White } N=17\end{array}$ \\
\hline AM & Respiratory rate BPM & $223.02 \pm 2.50^{\mathrm{a}}$ & $225.45 \pm 2.11^{\mathrm{a}}$ & $221.18 \pm 2.78^{\mathrm{a}}$ & $208.57 \pm 2.26^{\mathrm{b}}$ \\
& Heart rate HBPM & $166.38 \pm 5.38^{\mathrm{a}}$ & $145.33 \pm 4.95^{\mathrm{b}}$ & $163.03 \pm 6.13^{\mathrm{a}}$ & $162.06 \pm 5.40^{\mathrm{a}}$ \\
& Ear Temp ${ }^{\circ} \mathrm{C}$ & $34.05 \pm 0.33$ & $33.94 \pm 0.12$ & $33.62 \pm 0.12$ & $33.81 \pm 0.10$ \\
& Rectal Temp ${ }^{\circ} \mathrm{C}$ & $37.62 \pm 0.07^{\mathrm{a}}$ & $37.58 \pm 0.10^{\mathrm{a}}$ & $37.40 \pm 0.10 \mathrm{a}^{\mathrm{b}}$ & $37.29 \pm 0.09^{\mathrm{b}}$ \\
PM & Respiratory rate BPM & $226.73 \pm 2.42^{\mathrm{a}}$ & $225.63 \pm 2.15^{\mathrm{a}}$ & $225.75 \pm 2.88^{\mathrm{a}}$ & $217.21 \pm 2.31^{\mathrm{b}}$ \\
& Heart rate HBPM & $184.95 \pm 16.52^{\mathrm{a}}$ & $143.56 \pm 4.94^{\mathrm{ab}}$ & $164.44 \pm 6.82^{\mathrm{b}}$ & $162.40 \pm 5.83^{\mathrm{b}}$ \\
& Ear Temp ${ }^{\circ} \mathrm{C}$ & $34.39 \pm 0.11$ & $34.35 \pm 0.13$ & $38.71 \pm 3.05$ & $36.21 \pm 1.91$ \\
& Rectal Temp ${ }^{\circ} \mathrm{C}$ & $38.07 \pm 0.07^{\mathrm{a}}$ & $38.08 \pm 0.07^{\mathrm{a}}$ & $37.99 \pm 0.07^{\mathrm{a}}$ & $37.72 \pm 0.07^{\mathrm{b}}$ \\
& & &
\end{tabular}

$B P M$ breaths per minute, HBPM beat per minute, Temp temperature

$\mathrm{a}, \mathrm{b}$ and $\mathrm{c}^{\mathrm{M}}$ Means in the same row with different superscripts are significantly $(p<0.05)$ different

August was the most comfortable period during the year for rabbit as it has been reported that exposure to heat stress brings about response by animals to maintain homeostasis.

Akinsola (2012) reported temperature-humidity index THI in rabbitry averaged $27.3{ }^{\circ} \mathrm{C}$ absence of heat stress in cool period of the year in Northern Nigeria. This suggests that Northern Nigeria have higher THI than Southern Nigeria during the cooler periods. This could be attributed to study area's temperature distribution; Ibadan is within moderately hot area $\left(24-27{ }^{\circ} \mathrm{C}\right.$ mean annual temperature), while Zaria is within hottest area (over $27{ }^{\circ} \mathrm{C}$ mean annual temperature). In the study conducted by Marai, Habeeb, and Gad (2005), a THI value of $17.3{ }^{\circ} \mathrm{C}$ for mild period was reported in the subtropical climate of Egypt. The result obtained in this study showed that THI increased from 24.82 to 30.50 in July and from 24.05 to 26.05 in August from morning to evening, which is in agreement with Adenkola, Ayo, and Sackey (2009) who reported low THI in the morning and higher value in the afternoon.

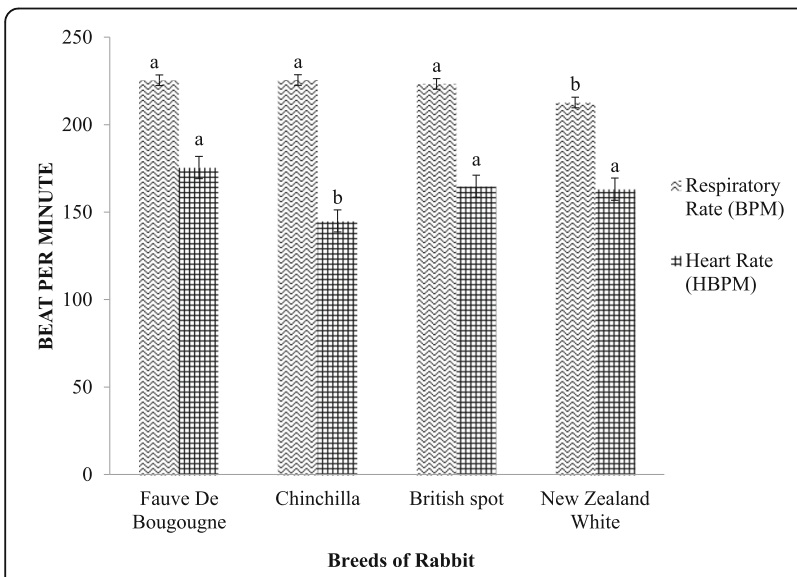

Fig. 2 Average daily respiratory and heart rates of four exotic breeds of rabbit during the least temperature-humidity index
Rabbits use general body position, breathing rate and peripheral temperature, especially ear, as the devices to control heat loss. However, respiration and ear are the most important dissipation pathways. Marai and Habeeb (1994) indicated that between 0 and $30{ }^{\circ} \mathrm{C}$, latent heat evacuation is only controlled by altering the breathing rate. The effect of sex was observed in respiratory and heart rates, with males having higher values in the evening. But the core body temperature was not affected. It could be suggested that the animals' response was due to the absence of heat stress. It has been reported that sexual differences in thermoregulatory activities could be observed more sensitively under hyperthermia (Massaro, Owen, \& Massaro, 2006).

New Zealand White have a lower core body temperature; this suggests an inherent genetic ability of the breed to regulate body temperature without a compensatory increase in thermoregulatory activities. This could be due to their white coat colour which absorbs less heat and reflects more compared to other coat colour. Fauve de Bourgogne and Chinchilla had similar respiratory rate throughout the day. Although the higher function of thermoregulatory

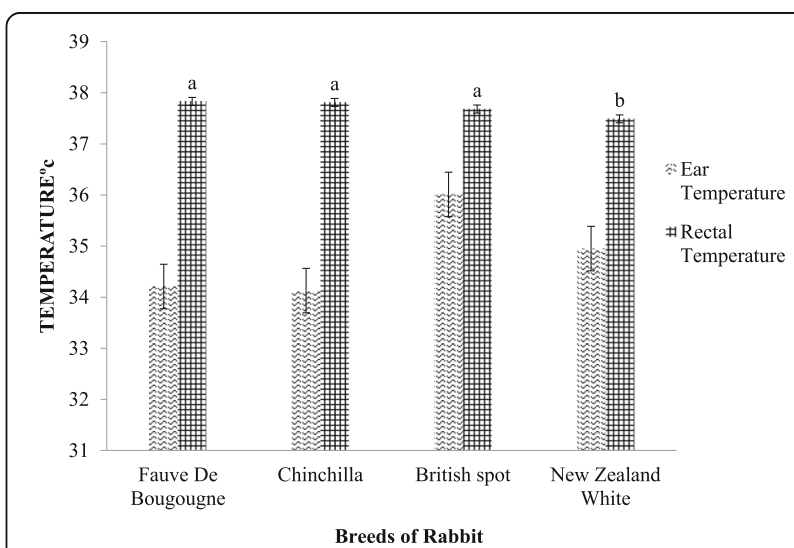

Fig. 3 Ear and rectal temperature of four exotic breeds of rabbit during least temperature-humidity-index 
apparatus of Fauve de Bourgogne, Chinchilla and British Spot rabbits were recorded, New Zealand White had lower core body temperature than other breeds. Akinsola (2012) reported increased thermoregulatory parameters in grandparent and $F_{1}$ progeny of Hyla rabbits in Northern Nigeria. This could suggest low susceptibility of New Zealand White rabbits to heat stress. The result obtained in this study is in line with the suggestion that breed differences exist in the rate of cutaneous cooling (Alexiev, Gudev, Popova, \& Moneva, 2004). The range of respiratory rates obtained was from 208.57 to $226.73 \mathrm{bpm}$, heart rates of 143.56 to 184.95 hbpm, ear temperature of 33.62 to $38.71{ }^{\circ} \mathrm{C}$ and rectal temperature of 37.29 to $38.08{ }^{\circ} \mathrm{C}$. The values of respiratory rate obtained in this study are higher than values obtained by Askar and Ismail (2012) that recorded $112 \mathrm{bpm}$ but lower rectal temperature of $38.5^{\circ} \mathrm{C}$ at THI of 20.8 for comfort conditions for rabbits in Egypt. This disparity could be due to differences in THI values, which required higher thermoregulatory activities in exotic breeds of rabbit in Ibadan to effectively lower body temperature, thus confer better thermoregulatory activities on the exotic breeds. The range of values for heart rate obtained in this study is within the lower limit of values reported for stress rabbits 180 to $300 \mathrm{bpm}$, and respiratory rates and rectal temperature are within the range indicated for stressed rabbits of 40 to $300 \mathrm{bpm}$ and 38 to $40{ }^{\circ} \mathrm{C}$ (Willmer, Stone, \& Johnston, 2000). Though the range of heart and respiratory rates obtained in this study is higher than reports in Egypt, it could be due to differences in breed and also acclimation of the Egyptian animals to their environment.

\section{Conclusions}

This study reveals that the month of August was the most thermal comfortable period during the year for rabbit in South Western, Nigeria. New Zealand White have a lower core body temperature, due to their white coat colour which absorbs less heat and reflects more compared to other coat colour. This is an inherent genetic ability of the breed to regulate body temperature without a compensatory increase in thermoregulatory activities. Although the higher function of thermoregulatory apparatus of Fauve de Bourgogne, Chinchilla and British Spot rabbits were recorded, New Zealand White had lower core body temperature than other breeds. New Zealand white has the highest thermal comfort ability in the study area and could have better resistance to heat stress among the breeds.

\section{Abbreviations \\ BS: British Spot; CHA: Chinchilla; ET: Ear temperature; FDB: Fauve De Bourgogne; HR: Heart rate; NZW: New Zealand White; RR: Respiratory rate; RT: Rectal temperature; THI: Temperature-humidity index}

\section{Acknowledgements}

The authors are grateful to the management and staff of the rabbitry unit, teaching and research farm, University of Ibadan, for their assistance in providing animals and housing for this work.

\section{Funding}

The research outcome presented in this article was jointly funded by the authors. This research did not receive any specific grant from any funding agency in the public, commercial or not-for-profit sector.

Availability of data and materials

Not applicable

\section{Authors' contributions}

JOA designed the study, carried out the field work and statistical analysis as part of his doctorate research and wrote the first manuscript. EOE approved the study layout and supervised the research; he read and corrected the first manuscript. Both authors read and approve the final manuscript.

\section{Ethics approval}

The study was approved by the institutional committee on the care and use of animals for the experiment and in accordance with $\mathrm{NIH}$ guide for the care and use of laboratory animals.

Consent for publication

Not applicable

\section{Competing interests}

The authors declare that they have no competing interests.

\section{Publisher's Note}

Springer Nature remains neutral with regard to jurisdictional claims in published maps and institutional affiliations.

Received: 19 September 2017 Accepted: 9 February 2018

Published online: 02 March 2018

\section{References}

Adenkola, A. Y., Ayo, J. O., \& Sackey, A. K. B. (2009). Ascorbic acid-induced modulation of rectal temperature in pigs during harmattan season. Journal of Thermal Biology, 34(3), 152-154.

Akinsola, O. M. (2012). Genetic and physiological evaluation of Hyla rabbits in guinea savannah zone of Nigeria, (pp. 66-70). Zaria: M.Sc. dissertation submitted to the Department of Animal Science, Ahmadu Bello University.

Alexiev, J., Gudev, D., Popova, S., \& Moneva, P. (2004). Thermoregulation in sheep. IV. Effect of heat stress on heart rate dynamics in shorn and inshorn ewes from three breeds. Zhovotnov dni-Nauki, 41(1), 169-171.

Altan, O., Pabuccuoglu, A., Alton, A., Konyalioglu, S., \& Bayraktar, H. (2003). Effect of heat stress on oxidative stress, lipid peroxidation and some stress parameters in broilers. British Poultry Science, 4, 545-550.

Askar, A. A., and Ismail, E. I., (2012). Impact of heat stress exposure on some reproductive and physiological traits of rabbit does. Egypt. Journal of Animal Production, 49, 151-159.

Collier, R. J., Dahl, G. E., \& VanBaale, M. J. (2006). Major advances associated with environmental effects on dairy cattle. Journal of Dairy Science, 89, 1244-1253.

Dobson, H., Tebble, J. E., Smith, R. F., \& Ward, W. R. (2001). Is stress really all that important? Theriodogenology, 55, 65-73.

Fuquay, J. W. (1981). Heat stress as it affects animal production. Journal of Animal Science, 52, 164-174.

Hansen, P. J. (2009). Review: Effects of heat stress on mammalian reproduction. Philosophical Transactions of the Royal Society B, 364, 3341-3350. https://doi. org/10.1098/rstb.2009.0131.

Ilori, B. M., Isidahomen, C. E., \& Akano, K. (2012). Effect of ambient temperature on reproductive and physiological traits of Nigerian indigenous chickens. Journal of Animal Production Advances, 211, 477-489.

Jimoh, O. A. (2016). Assessment of the oxidative stress markers and reproductive performance of four exotic breeds of rabbit in Ibadan. Ibadan: Ph.D Thesis, University of Ibadan.

Kimothi, S. P., \& Ghosh, C. P. (2005). Strategies for ameliorating heat stress in dairy animals. Dairy Year book, 4th edition, 371-377.

Marai, I. F. M., Ayyat, M. S., \& Abd El-Monem, U. M. (2001). Growth performance and reproductive traits at first parity of New Zealand White female rabbits as affected by heat stress and its alleviation, under Egyptian conditions. Tropical Animal Health and Production, 33, 1-12. 
Marai, I. F. M., Habeeb, A. A. M., \& Gad, A. E. (2005). Tolerance of imported rabbits grown as meats animals to hot climate and saline drinking water in the subtropical environment of Egypt. Proceedings of the British Society of Animal Science, 81, 115-123.

Marai, I. F. M., \& Habeeb, A. A. M. (1994). Thermoregulation in rabbits. Options Méditerranéennes, 8, 33-41.

Massaro, D., Owen, G., \& Massaro, G. D. (2006). Estrogen receptor regulation of pulmonary alveolar dimensions: alveolar sexual dimorphism in mice. American Journal of Physiology. Lung Cellular and Molecular Physiology, 290, L866-L870.

Maya-Soriano, M. J. (2012). Heat stress and antioxidant agents: Effects on gamete development, (p. 120). PhD. dissertaation at Animal medicine and Anatomy, Universitat Autonoma de Barcelona, Barcelona, Spain.

Morrison, S. R. (1983). Ruminant heat stress: effect on production and means of alleviation. Journal of Animal Science, 57, 1594-1600.

Naqvi, S. M. K., Gulyani, R., \& Singh, G. (1995). Physiological responses of broiler rabbits in hot semi-arid environment. The Indian Journal of Animal Sciences, 65, 718-720.

Willmer, P., Stone, G., \& Johnston, J. (2000). Environmental physiology of animals, (1st ed., p. 672). Oxford: Blackwell Scientific Publications.

\section{Submit your manuscript to a SpringerOpen ${ }^{\odot}$ journal and benefit from:}

- Convenient online submission

- Rigorous peer review

- Open access: articles freely available online

- High visibility within the field

- Retaining the copyright to your article

Submit your next manuscript at $\gg$ springeropen.com 